\title{
AGRONOMIC PERFORMANCE OF SESAME (Sesamum indicum L.) GENOTYPES UNDER PHYTOSTIMULANT APPLICATION
}

\author{
DESEMPENHO AGRONÔMICO DE GENÓTIPOS DE GERGELIM (Sesamum \\ indicum L.) SOB APLICAÇÃO DE FITOESTIMULANTE
}

\section{Jeandson Silva VIANA ${ }^{1}$; Djayran Sobral COSTA ${ }^{2}$; Juliana Joice Pereira LIMA ${ }^{3}$; Edilma Pereira GONÇALVES ${ }^{1}$; Nair Helena Castro ARRIEL ${ }^{4}$; José Fábio Ferreira de OLIVEIRA ${ }^{2}$}

1. Professor(a) Doutor(a), Universidade Federal Rural de Pernambuci - UFRPE, Unidade Acadêmica de Garanhuns, PE, Brasil. jeandson.viana@ufrpe.br; 2. Mestre em Produção Agrícola - UFRPE, Unidade Acadêmica de Garanhuns, PE, Brasil, 3. Professora, Doutora, Universidade Federal do Piauí - UFPI, Bom Jesus, PI, Brasil, 4. Pesquisadora, Doutora, EMBRAPA, CNPA, Campina Grande, $\mathrm{PB}$, Brasil.

\begin{abstract}
Sesame (Sesamum indicum L.) is one of the oldest cultivated plant species and become an important alternative to reduce food deficiency in low income populations. Growth regulators influence protein metabolism and may increase the rate of enzyme synthesis involved in the process of seed germination, rooting, flowering, and fruiting of plants. This study aimed to evaluate the agronomic performance of sesame genotypes under the influence of the bioregulator Stimulate ${ }^{\circledR}$ in two agricultural years in the northeastern region of Brazil. The experiment was carried out in the dry and wet seasons (agricultural years 2014 and 2015, respectively) in the city of Garanhuns in the state of Pernambuco. The experiment was carried out in randomized blocks using four genotypes of sesame (BRS SEDA, CNPA G4, Lineage 1, and Lineage 2), with and without application of the phytostimulant (Stimulate ${ }^{\circledR}$ ). Phytostimulant application did not influence root length. However, it resulted in an increase in the number of fruits per plant, and for genotypes Lineage 1 and Lineage 2, an increase in the content of chlorophyll A and B. Thus, the application of phytostimulant increases the yield of sesame; however, the response to phytostimulant application varies with the genotype and growth conditions.
\end{abstract}

KEYWORDS: Productivity. Plant growth regulator. Plant yield.

\section{INTRODUCTION}

Sesame (Sesamum indicum L.) is an annual herbaceous plant, originating in the African continent, belonging to the pedaliaceous family, and has medicinal properties. It has white, pink, or red flowers; they are also hermaphrodites, arranged in the axis of leaves. The fruit is a capsule, oblong, pubescent, with oilseeds, which are small, yellow, white, or black, rounded, and lightly compressed. Sesame is considered one of the oldest plant species in the world (FRANCIS, 2013).

Sesame is an annual plant, autogamous, with erect stem, sometimes branching, and measures between 0.6 and $1.3 \mathrm{~m}$ in height. The crop requires only $500-650 \mathrm{~mm}$ of precipitation annually and is tolerant to drought conditions during its vegetative stage (BOUREIMA et al., 2011). The ideal temperature for the crop is approximately $20-35^{\circ} \mathrm{C}$. The plant is also adaptable to many types of soil, but grows best in fertile soils that are well-drained and of medium texture. The cultivation of sesame is somewhat restricted, because it does not grow well in clayey, heavy, and water-logged soils (MISGANAW et al., 2015).
Because of its potential, sesame is an important alternative to minimize food shortage in low income populations. Internationally, products containing sesame (food, cosmetics, and pharmacology) have increased, generating demand for this "in natura" product. With the world market on the rise, the possibilities for exporting the national crop for Brazil have increased, since sesame is used in the bakery and biscuit industries, as well as in oil production for human consumption (YOUSEFZADEH; EHSANZADEH, 2017).

Sesame plant has a wide adaptability to regions with tropical and subtropical climates, but can still be cultivated in temperate zones of milder climate (ARRIEL et al., 2007). It is an oleaginous short season crop that can be harvested within three months. This allows for fast cultivation, increasing the potential of harvesting, intensification, and diversification of agricultural systems; in addition, sesame cultivation is considered simple and easy (OYEOGBE et al., 2015).

Plants constantly perform metabolic processes, and for improved efficiency of these processes, it is necessary to make use of plant hormones, which are organic substances that can influence the physiological processes of plants, 
mainly cell growth, differentiation, and vegetative development (PHILOSOPH-HADAS et al., 2005; KUCERA et al., 2005).

Growth regulators influence protein metabolism, which may increase the rate of enzyme synthesis involved in the process of seed germination, rooting, flowering, and fruiting of plants (BOURSCHEIDT, 2011). The Stimulate ${ }^{\circledR}$ bioregulator is a combination of three plant regulators, cytokinins, gibberellins, and auxins, providing amino acids, nutrients, and vitamins to the plants. It can also be called a stimulator, phytostimulant, or even biostimulant (CATO, 2006).

In the northeast region of Brazil, sesame has not yet become an economically important crop despite suitable climatic conditions for its development; it is cultivated manually by small producers who use traditional technologies, low agricultural inputs, and genotypes with low vigor (SILVA et al., 2016). Because of these problems and the low productivity of sesame compared to other oleaginous plants, alternatives are sought to increase productivity, such as the use of new genotypes that are better adapted to the environmental conditions and the use of phytostimulants, which are hormones used in agriculture with the objective of improving crop productivity.
We aimed to evaluate the agronomic performance of sesame genotypes with the application of the phytostimulant Stimulate ${ }^{\circledR}$ during the rainy and dry seasons in the northeast of Brazil.

\section{MATERIAL AND METHODS}

The experiment was carried out in the 2014 and 2015, in two distinct areas belonging to the Academic Unit of Garanhuns - UAG, located in the city of Garanhuns, state of Pernambuco, which has geographic coordinates of $36^{\circ} 29^{\prime}$ west longitude and $08^{\circ} 53^{\prime}$ south latitude, and altitude of approximately $896 \mathrm{~m}$.

Physical and chemical analyses of the soil (Table 1) were performed for cultivation in both the wet season of 2014 and the dry season of 2015. The application of nitrogen fertilizer $\left(25 \mathrm{~kg} \mathrm{ha}^{-1}\right)$, simple superphosphate $\left(40 \mathrm{~kg} \mathrm{ha}^{-1}\right)$ and potassium chloride $\left(20 \mathrm{~kg} \mathrm{ha}^{-1}\right)$ were performed in the planting furrow at the time of sowing, following the recommendation of the fertilization manual of the Instituto Agronômico de Pernambuco (CAVALCANTE, 2008). In the two cultivation areas, the soil was prepared with a plowing and two cross gradations, for decompression and the breaking of clods.

Table 1. Physical and chemical analysis of soils for sesame planting during the water season (2014) and dry season (2015) at UFRPE / UAG.

Physical analysis

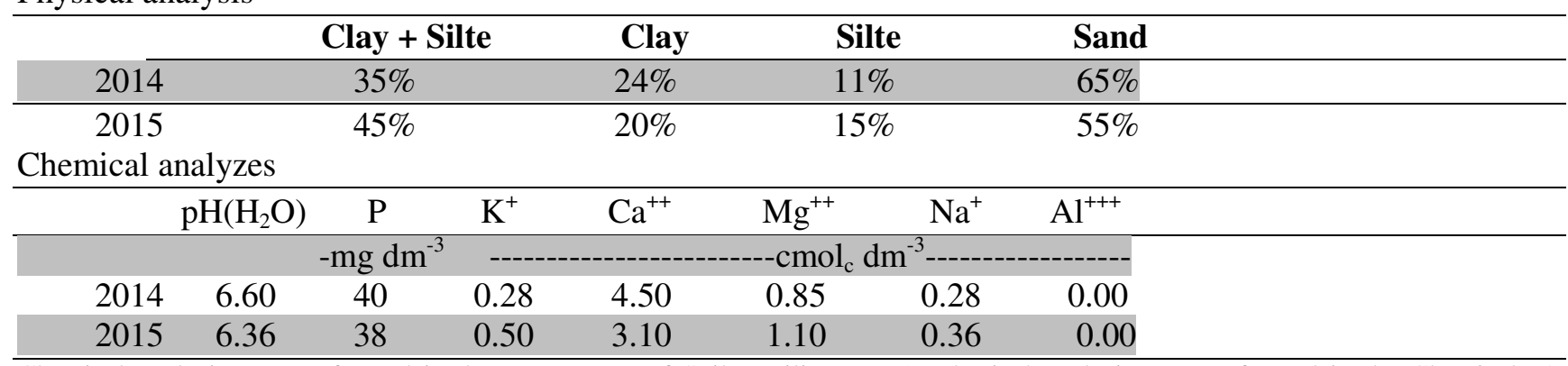

Chemical analysis was performed in the Department of Soil Fertility at IPA. Physical analysis was performed in the Chemicals \& Fertility Laboratory of Soil at UAG / UFRPE.

One experiment was carried out in the wet season (winter months), where sowing was performed on 06/07/2014, and harvesting on $12 / 07 / 2014$; the another experiment was carried out during the dry season (summer months) in which the sowing was performed on 01/27/2015, and harvesting on $05 / 27 / 2015$. For the two experiments, 15 seeds were sown followed by thinning after 21 days; 10 seedlings per linear meter with four rows of four meters were left at a spacing of $0.40 \mathrm{~m}$ between rows and a total area of $160 \mathrm{~m}^{2}(20.0 \times 8.0$ $\mathrm{m})$, each plot measuring $4.8 \mathrm{~m}^{2}(4.0 \times 1.20 \mathrm{~m})$ in four (4) blocks.

Hand weeding was carried out for weed control 15 days after planting, and every 15 days subsequently, in order to reduce damage in the sesame plants due to competition with weeds. Pests were sampled in the area with the objective of detecting and identifying the level of economic damage to the sesame crop; results indicated no need for control. 
In the wet season the irrigation system was not utilized because there was $650 \mathrm{~mm}$ of rainfall during the crop cycle (Figure 1A); on days when there was no rain, manual irrigation with a watering aid was used to prevent damage to the crop. For the cultivation in the dry season, the rainfall occurrence was around $120 \mathrm{~mm}$ in the whole crop cycle (Figure
1B); therefore, an irrigation system was implemented with the use of micro sprinklers, supplying $0.6 \mathrm{~mm}$ of water daily in the growth stage, $7 \mathrm{~mm}$ at pre-flowering, $5 \mathrm{~mm}$ at grain filling, and $2 \mathrm{~mm}$ thereafter for the maintenance of the crop when there was no precipitation.

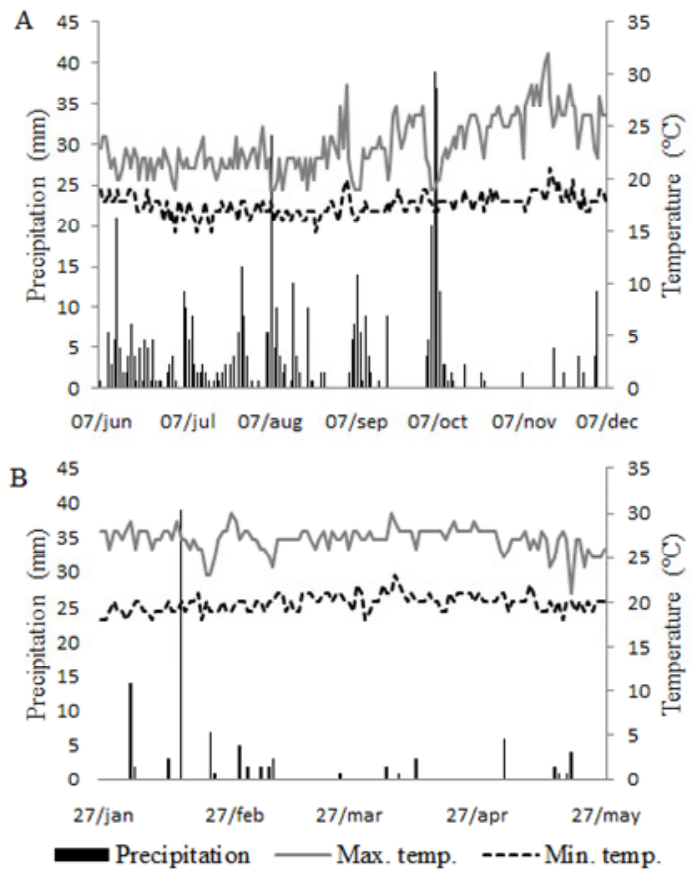

Figure 1. Temperatures and precipitation of the months at the area of experiment in the water season (2014-A) and in the dry season (2015-B). Garanhuns-PE, 2015 Source: INMET (2015).

The genotypes used were BRS SEDA, CNPA G4, Lineage 1, and Lineage 2, from EMBRAPA/Algodão. Stimulate ${ }^{\circledR}$ was applied to the seed at the time of sowing at a rate of $20 \mathrm{ml}$ to 1 (one) kilo of sesame seeds and the foliar application was at $30 \mathrm{ml}$ to one liter of water being sprayed on plants of 15 in 15 days as indicated on the product label, until the beginning of the plant maturation.

Harvesting for the two experiments was done on sunny days as follows: manually cutting the base of the plants, tying the harnesses with twine and then piling them in the field on a plastic canvas to avoid losing seeds and moisture content.

Evaluations of the following agronomic characteristics were carried out in the useful area, using 10 plants per plot: shoot length (SHOOT) and root length (ROOT), obtained by direct measurement of the shoot and root with millimeter rule (FLOSS, 2008); number of fruits per plant (NUMFP), the number of fruits of each plant harvested within the plot was counted (FLOSS, 2008); biological productivity (BPROD), obtained by weighing the green material (FLOSS, 2008); grain productivity (GPROD), obtained by the average of the plants within the treatments (FLOSS, 2008); content of chlorophyll A (CCA) and chlorophyll B (CCB), obtained using chloroflOG equipment by using the fourth leaf from the top during flowering (FLOSS, 2008).

The experiment was carried out in a randomized complete block design $(4 \times 2)$. The plots were four genotypes (BRS SEDA, CNPA G4, Lineage 1 and Lineage 2), and subplots with and without phytostimulant $\left(\right.$ Stimulate $\left.^{\circledR}\right)$. The data were subjected to analysis of variance and the means were compared using the Tukey test at the 5\% probability level.

\section{RESULTS AND DISCUSSION}

The results of soil chemical analysis showed that the $\mathrm{pH}$ was adequate for the growth and development of sesame, with values of 6.6 and 6.3 for soils in 2014 and 2015, respectively (Table 1). 
Soil with $\mathrm{pH}$ close to 7 is optimal for sesame growth, since sesame does not grow well in soils with $\mathrm{pH}$ below 5.5 or above 8 ; these reduce the establishment of the crop, including the emergence of plants (SILVA et al., 2016).

The average temperatures were $22^{\circ} \mathrm{C}$ in 2014 and $25^{\circ} \mathrm{C}$ in 2015 (Figure 1). These temperatures are ideal for sesame cultivation; lower temperatures during the maturation period affect seed and oil quality, interfering with sesamin and sesamoline contents (ARRIEL et al., 2007).

Table 2 shows the mean values of shoot length of sesame plants for the two crop years. The increased height of the plants in this study can be attributed to the genotypes used, environmental conditions, and crop management. For cultivation in the wet season (2014), it is observed that the genotypes Lineage 1 and Lineage 2 with Stimulate ${ }^{\circledR}$ had longer shoots, but they did not differ statistically from genotype BRS SEDA. In general, in the different crop years, no statistical differences for height of the plants were noted among the genotypes; therefore, it can be inferred that the superiority in height is related to the management of the crop and to the use of the phytostimulant. For cultivation in the dry season (2015), Table 2 shows that neither the Stimulate ${ }^{\circledR}$ nor the genotype had any significant effect, except for the CNPA G4 genotype, which showed a lower height in the absence of phytostimulant.

Table 2. Length of shoot (SHOOT) of plants of four sesame (Sesamum indicum L.) genotypes, with Stimulate ${ }^{\circledR}$ (WITH) and without Stimulate ${ }^{\circledR}$ (WITHOUT) in the water season (2014) and in the dry season (2015). Garanhuns-PE.

\begin{tabular}{|c|c|c|c|c|c|c|}
\hline \multicolumn{7}{|l|}{ SHOOT (m) } \\
\hline \multirow[t]{2}{*}{ Genotypes } & \multicolumn{3}{|c|}{ Water season (2014) } & \multicolumn{3}{|c|}{ Dry season (2015) } \\
\hline & WITH & WITHOUT & Mean & WITH & WITHOUT & Mean \\
\hline BRS SEDA & $1.277 \mathrm{abA}$ & $0.949 \mathrm{aA}$ & $1.187 \mathrm{a}$ & $1.290 \mathrm{aA}$ & $1.215 \mathrm{aA}$ & $1.252 \mathrm{a}$ \\
\hline Lineage 1 & $1.333 \mathrm{abA}$ & $0.930 \mathrm{aB}$ & $1.250 \mathrm{a}$ & $1.270 \mathrm{aA}$ & $1.035 \mathrm{aA}$ & $1.157 \mathrm{a}$ \\
\hline Lineage 2 & $1.737 \mathrm{aA}$ & $0.998 \mathrm{aB}$ & $1.500 \mathrm{a}$ & $1.030 \mathrm{aA}$ & $1.175 \mathrm{aA}$ & $1.101 \mathrm{a}$ \\
\hline CNPA G4 & $1.138 \mathrm{bA}$ & $0.883 \mathrm{aA}$ & $0.975 \mathrm{a}$ & $1.370 \mathrm{aA}$ & $0.945 \mathrm{aB}$ & $1.161 \mathrm{a}$ \\
\hline Mean & $1.468 \mathrm{~A}$ & $0.937 \mathrm{~B}$ & & $1.240 \mathrm{~A}$ & $1.092 \mathrm{~A}$ & \\
\hline $\mathrm{Cv}$ column $(\%)$ & 12.77 & & & 17.20 & & \\
\hline $\mathrm{Cv} \operatorname{row}(\%)$ & 16.49 & & & 14.99 & & \\
\hline LSD column & 0.80 & & & 0.49 & & \\
\hline LSD row & 0.86 & & & 0.52 & & \\
\hline
\end{tabular}

* Means followed by the same lowercase letter in the column and capital letter in the row do not differ by Tukey test at the level of $5 \%$.

Table 3 shows the mean values for root length in the two crop seasons. In the wet season (2014) the sesame plants of the genotype Lineage 1 without Stimulate ${ }^{\circledR}$ showed lower root length, differing from the other genotypes. For the simple effect, it was observed that there were no differences in the lengths of the roots of the different genotypes in the two crop years (Table 3 ). Magalhães \& Vieira (2008) report in their work that a high concentration of auxin from the use of plant hormones inhibits root growth, since the roots of plants are very sensitive to this plant regulator. Castro \& Vieira (2003) analyzed the application of Stimulate $^{\circledR}$ on a bean crop, and noted that after the third application there was a significant effect on root length. For the current study, it can be inferred that the use of Stimulate ${ }^{\circledR}$ influenced root length only in the wet season, because according to Silva et al. (2014) the roots of sesame only absorb nutrients and inputs generally in soils with satisfactory humidity.

For the evaluation of the number of fruits per plant of sesame in the wet season (2014), it was observed that the plants of all the genotypes with Stimulate $^{\circledR}$ produced a greater number of fruits compared to the plants without Stimulate ${ }^{\circledR}$ (Table 4). Considering the isolated genotypes, BRS SEDA, and CNPA G4 had the lowest mean number of fruits. Silva et al. (2014) report that these two genotypes are expected to produce a similar number of fruits per plant.

According to Beltrão \& Vieira (2001), studies evaluating the plasticity of the sesame plant, that is, its adaptability in different growing locations, show that the number of pods is determined during the final vegetative and reproductive stages. The interception of light by the plant community is fundamental for the development of reproductive buds, storage of photoassimilates and reduction of flower abortion and loss of pods. For the cultivation of sesame in the dry season (2015), the genotypes Lineage 1 and CNPA G4 with Stimulate ${ }^{\circledR}$ produced a highest number of fruits (Table 4). For the means of the isolated genotypes it is noticed that there were no differences in relation to the number of fruits. 
Tabela 3. Root length (ROOT) of plants of four sesame (Sesamum indicum L.) genotypes, with Stimulate ${ }^{\circledR}$ (WITH) and without Stimulate ${ }^{\circledR}$ (WITHOUT) in the water season (2014) and in the dry season (2015). Garanhuns-PE.

\begin{tabular}{|c|c|c|c|c|c|c|}
\hline \multicolumn{7}{|c|}{ ROOT $(\mathrm{cm})$} \\
\hline \multirow[t]{2}{*}{ Genotypes } & \multicolumn{3}{|c|}{ Water season (2014) } & \multicolumn{3}{|c|}{ Dry season (2015) } \\
\hline & WITH & WITHOUT & Mean & WITH & WITHOUT & Mean \\
\hline BRS SEDA & $6.829 \mathrm{aA}$ & $6.705 \mathrm{aA}$ & $6.750 \mathrm{a}$ & $5.300 \mathrm{aA}$ & $5.400 \mathrm{aA}$ & $5.350 \mathrm{a}$ \\
\hline Lineage 1 & $8.855 \mathrm{aA}$ & $6.880 \mathrm{aB}$ & $7.875 \mathrm{a}$ & $5.950 \mathrm{aA}$ & $5.775 \mathrm{aA}$ & $5.862 \mathrm{a}$ \\
\hline Lineage 2 & $8.100 \mathrm{aA}$ & $7.457 \mathrm{aA}$ & $7.625 \mathrm{a}$ & $5.725 \mathrm{aA}$ & $5.850 \mathrm{aA}$ & $5.787 \mathrm{a}$ \\
\hline CNPA G4 & $5.365 \mathrm{aA}$ & $4.880 \mathrm{aA}$ & $5250 \mathrm{a}$ & $5.100 \mathrm{aA}$ & $5.025 \mathrm{aA}$ & $6.062 \mathrm{a}$ \\
\hline Mean & $7.312 \mathrm{~A}$ & $6.437 \mathrm{~B}$ & & $5.345 \mathrm{~A}$ & $1.092 \mathrm{~A}$ & \\
\hline $\mathrm{Cv}$ column $(\%)$ & 13.77 & & & 10.53 & & \\
\hline $\mathrm{Cv}$ row $(\%)$ & 12.77 & & & 3.32 & & \\
\hline LSD column & 5.77 & & & 0.90 & & \\
\hline LSD row & 5.81 & & & 0.91 & & \\
\hline
\end{tabular}

* Means followed by the same lowercase letter in the column and capital letter in the row do not differ by Tukey test at the level of $5 \%$.

Table 4. Number of fruits per plant (NUMFP) of plants of four sesame (Sesamum indicum L.) genotypes, with Stimulate $^{\circledR}$ (WITH) and without Stimulate ${ }^{\circledR}$ (WITHOUT) in the water season (2014) and in the dry season (2015). Garanhuns-PE.

\begin{tabular}{|c|c|c|c|c|c|c|}
\hline \multicolumn{7}{|c|}{ NUMFP (units) } \\
\hline \multirow[t]{2}{*}{ Genotypes } & \multicolumn{3}{|c|}{ Water season (2014) } & \multicolumn{3}{|c|}{ Dry season (2015) } \\
\hline & WITH & WITHOUT & Mean & WITH & WITHOUT & Mean \\
\hline BRS SEDA & $54,00 \mathrm{bA}$ & $25.00 \mathrm{aB}$ & $40.00 \mathrm{~b}$ & $27.00 \mathrm{aA}$ & $17.00 \mathrm{aA}$ & $22.00 \mathrm{a}$ \\
\hline Lineage 1 & $74.00 \mathrm{aA}$ & $42.00 \mathrm{aB}$ & $58.00 \mathrm{a}$ & $33.00 \mathrm{aA}$ & $17.00 \mathrm{aB}$ & $25.00 \mathrm{a}$ \\
\hline Lineage 2 & $79.00 \mathrm{aA}$ & $40.00 \mathrm{aB}$ & $60.00 \mathrm{a}$ & $20.00 \mathrm{aA}$ & $20.00 \mathrm{aA}$ & $21.00 \mathrm{a}$ \\
\hline CNPA G4 & $55.00 \mathrm{bA}$ & $29.00 \mathrm{aB}$ & $42.00 \mathrm{~b}$ & $35.00 \mathrm{aA}$ & $13.00 \mathrm{aB}$ & $23.00 \mathrm{a}$ \\
\hline Mean & $66.00 \mathrm{~A}$ & $34.00 \mathrm{~B}$ & & $29.00 \mathrm{~A}$ & $17.00 \mathrm{~A}$ & \\
\hline $\mathrm{Cv}$ column $(\%)$ & 16.05 & & & 14.03 & & \\
\hline $\mathrm{Cv}$ row $(\%)$ & 15.56 & & & 17.38 & & \\
\hline LSD column & 20.12 & & & 11.99 & & \\
\hline LSD row & 5.96 & & & 7.18 & & \\
\hline
\end{tabular}

* Means followed by the same lowercase letter in the column and capital letter in the row do not differ by Tukey test at the level of $5 \%$.

The amount of fruit produced by sesame plants is directly related to the emission of new productive branches and the productivity of the plant (ANASTASI et al., 2017). Pereira et al. (2002), studying five levels of organic fertilization with bovine manure during two consecutive years in a sesame crop under dry conditions in the Seridó region of the state of Paraíba, verified that organic fertilization influenced the number of fruits in the sesame cultivar CNPA G3, and it showed the best response when water availability was low. The present study, however, showed that the use of Stimulate $^{\circledR}$ increased the number of fruits when cultivated in the wet season.

Table 5 shows the results of the chlorophyll A content of the leaves of the four sesame genotypes in the two crop years. In the wet season (2014) it is noticed that the plants of the genotypes Lineage 1 and Lineage 2 with Stimulate ${ }^{\circledR}$ presented higher content of chlorophyll A. The superiority of the genotypes Lineage 1 and Lineage 2 was also verified when compared to the other genotypes with the use of the bioregulator. In the dry season (2015), plants of the genotypes BRS SEDA and CNPA G4 with Stimulate ${ }^{\circledR}$ showed a chlorophyll A content higher than the plants of the other genotypes (Table 5). For the mean of the simple effect, it is observed that the highest average of the chlorophyll A content of sesame leaves was found in plants of genotype CNPA G4 which does not differ from BRS SEDA genotype.

According to Stirbet \& Govindjee (2011) the chlorophyll A fluorescence content has been used to evaluate the effect of environmental factors on photosynthetic metabolism, as well as to measure the degree of tolerance of plants to abiotic stresses. Chlorophyll content analysis can be performed using a portable equipment that makes a classical determination of the photosynthetic pigments in the sesame crop by mathematical means. The reading obtained through equipment such as the ClorofiLOG ${ }^{\circledR}$ corroborates with photosensitizing pigment results obtained by spectrometry in sesame leaves. It is therefore possible to determine 
photosynthetic compounds using the portable chlorophyllometer and through the application of time-adjusted mathematic models and reagents (RIGON et al., 2012).

Table 5. Content f Chlorophyll A (CCA) of plants of four sesame (Sesamum indicum L.) genotypes, with Stimulate $^{\circledR}$ (WITH) and without Stimulate ${ }^{\circledR}$ (WITHOUT) in the water season (2014) and in the dry season (2015). Garanhuns-PE.

\begin{tabular}{|c|c|c|c|c|c|c|}
\hline \multicolumn{7}{|c|}{ CCA (nm) } \\
\hline \multirow{2}{*}{ Genotypes } & \multicolumn{3}{|c|}{ Water season (2014) } & \multicolumn{3}{|c|}{ Dry season (2015) } \\
\hline & WITH & WITHOUT & Mean & WITH & WITHOUT & Mean \\
\hline BRS SEDA & $35.76 \mathrm{bA}$ & $34.27 \mathrm{aA}$ & $35.00 \mathrm{~b}$ & $86.25 \mathrm{aA}$ & $30.72 \mathrm{aB}$ & $58.50 \mathrm{a}$ \\
\hline Lineage 1 & $80.96 \mathrm{aA}$ & $29.78 \mathrm{aB}$ & $55.37 \mathrm{a}$ & $36.07 \mathrm{bA}$ & $33.81 \mathrm{aA}$ & $35.07 \mathrm{~b}$ \\
\hline Lineage 2 & $80.60 \mathrm{aA}$ & $29.80 \mathrm{aB}$ & $55.12 \mathrm{a}$ & $34.21 \mathrm{bA}$ & $34.18 \mathrm{aA}$ & $34.25 \mathrm{~b}$ \\
\hline CNPA G4 & $35.69 \mathrm{bA}$ & $32.54 \mathrm{aA}$ & $34.07 \mathrm{~b}$ & $90.37 \mathrm{aA}$ & $30.90 \mathrm{aB}$ & $60.73 \mathrm{a}$ \\
\hline Mean & $58.25 \mathrm{~A}$ & $31.59 \mathrm{~B}$ & & $61.72 \mathrm{~A}$ & $31.75 \mathrm{~B}$ & \\
\hline $\mathrm{Cv}$ column $(\%)$ & 7.68 & & & 4.42 & & \\
\hline $\mathrm{Cv}$ row $(\%)$ & 4.48 & & & 4.91 & & \\
\hline LSD column & 5.38 & & & 3.74 & & \\
\hline LSD row & 6.75 & & & 4.23 & & \\
\hline
\end{tabular}

* Means followed by the same lowercase letter in the column and capital letter in the row do not differ by Tukey test at the level of $5 \%$.

Table 6 shows the average results of the chlorophyll B content in the four genotypes of sesame in the two growing seasons, and it is noticed that the presence of phytostimulant had a positive effect for some genotypes. In the rainy season
(2014) it is noticed that the plants of the genotypes Lineage 1 and Lineage 2 with Stimulate ${ }^{\circledR}$ had a chlorophyll B content higher than the other genotypes.

Tabela 6. Content of Chlorophyll B (CCB) of plants of four sesame (Sesamum indicum L.) genotypes, with Stimulate $^{\circledR}$ (WITH) and without Stimulate ${ }^{\circledR}$ (WITHOUT) in the water season (2014) and in the dry season (2015). Garanhuns-PE.

\begin{tabular}{|c|c|c|c|c|c|c|}
\hline \multicolumn{7}{|c|}{$\mathrm{CCB}(\mathrm{nm})$} \\
\hline \multirow[t]{2}{*}{ Genotypes } & \multicolumn{3}{|c|}{ Water season (2014) } & \multicolumn{3}{|c|}{ Dry season (2015) } \\
\hline & WITH & WITHOUT & Mean & WITH & WITHOUT & Mean \\
\hline BRS SEDA & $9.20 \mathrm{bA}$ & $8.32 \mathrm{abA}$ & $8.75 \mathrm{~b}$ & $18.53 \mathrm{aA}$ & $6.08 \mathrm{aB}$ & $12.30 \mathrm{a}$ \\
\hline Lineage 1 & $17.54 \mathrm{aA}$ & $6.31 \mathrm{abB}$ & $11.93 \mathrm{a}$ & $8.33 \mathrm{bA}$ & $7.67 \mathrm{aA}$ & $8.30 \mathrm{~b}$ \\
\hline Lineage 2 & $17.44 \mathrm{aA}$ & $6.24 \mathrm{bB}$ & $11.75 \mathrm{a}$ & $8.37 \mathrm{bA}$ & $7.67 \mathrm{aA}$ & $7.93 \mathrm{~b}$ \\
\hline CNPA G4 & $8.77 \mathrm{bA}$ & $8.52 \mathrm{aA}$ & $8.73 \mathrm{~b}$ & $18.51 \mathrm{aA}$ & $8.81 \mathrm{aB}$ & $12.16 \mathrm{a}$ \\
\hline Mean & $13.23 \mathrm{~A}$ & $7.34 \mathrm{~B}$ & & $13.43 \mathrm{~A}$ & $6.75 \mathrm{~B}$ & \\
\hline Cv column $(\%)$ & 11.82 & & & 8.06 & & \\
\hline $\mathrm{Cv}$ row $(\%)$ & 8.14 & & & 4.85 & & \\
\hline LSD column & 1.90 & & & 1.27 & & \\
\hline LSD row & 1.12 & & & 1.76 & & \\
\hline
\end{tabular}

* Means followed by the same lowercase letter in the column and capital letter in the row do not differ by Tukey test at the level of $5 \%$.

The evaluation of the chlorophyll B content in the leaves of the plants is very important because it is closely related to the nitrogen absorption by the plant (NEVES et al., 2005). According to Argenta et al. (2001), there is a relationship between nitrogen content in the leaves and chlorophyll content; this is justified by the participation of nitrogen in the chloroplasts in the vegetal tissue, giving it the green coloration. In the dry season (2015), plants of the genotypes BRS SEDA and CNPA G4 with Stimulate $^{\circledR}$ had a chlorophyll B content higher than the other genotypes (Table 6). For the simple effects the highest averages of chlorophyll B content were found in the BRS SEDA and CNPA G4 genotypes.

In the evaluation of biological productivity in the wet season, the plants of the genotypes Lineage 1 and Lineage 2 with Stimulate ${ }^{\circledR}$ had higher biological productivity than plants of the other genotypes (Table 7). Azevedo et al. (2003) state that to obtain good biological productivity in sesame it is necessary to make use of new genotypes with seed of high physiological quality. 
Table 7. Biological productivity (BPROD) of plants of four sesame (Sesamum indicum L.) genotypes, with Stimulate $^{\circledR}$ (WITH) and without Stimulate ${ }^{\circledR}$ (WITHOUT) in the water season (2014) and in the dry season (2015). Garanhuns-PE.

\begin{tabular}{|c|c|c|c|c|c|c|}
\hline \multicolumn{7}{|c|}{ BPROD Kg.ha ${ }^{-1}$} \\
\hline \multirow[t]{2}{*}{ Genotypes } & \multicolumn{3}{|c|}{ Water season (2014) } & \multicolumn{3}{|c|}{ Dry season (2015) } \\
\hline & WITH & WITHOUT & Mean & WITH & WITHOUT & Mean \\
\hline BRS SEDA & $14055.0 \mathrm{bA}$ & 8097.0 bA & $11076.0 \mathrm{~b}$ & $21560.0 \mathrm{aA}$ & $15600.0 \mathrm{aA}$ & $18580.0 \mathrm{a}$ \\
\hline Lineage 1 & $26923.0 \mathrm{aA}$ & $19428.0 \mathrm{aB}$ & $23175.0 \mathrm{a}$ & $14680.0 \mathrm{bA}$ & $13710.0 \mathrm{aA}$ & $14195.0 \mathrm{a}$ \\
\hline Lineage 2 & $32800.0 \mathrm{aA}$ & $20302.0 \mathrm{aB}$ & $26551.0 \mathrm{a}$ & $15480.0 \mathrm{bA}$ & $15030.0 \mathrm{aA}$ & $15255.0 \mathrm{a}$ \\
\hline CNPA G4 & $11238.0 \mathrm{bA}$ & $7276.0 \mathrm{bA}$ & $9257.0 \mathrm{~b}$ & $26720.0 \mathrm{aA}$ & $9020.0 \mathrm{aB}$ & $17870.0 \mathrm{a}$ \\
\hline Mean & $21254.0 \mathrm{~A}$ & $13775.0 \mathrm{~B}$ & & $19610.0 \mathrm{~A}$ & $13340,0 \mathrm{~B}$ & \\
\hline $\mathrm{Cv}$ column $(\%)$ & 27.94 & & & 38.77 & & \\
\hline $\mathrm{Cv}$ row $(\%)$ & 29.01 & & & 28.32 & & \\
\hline LSD column & 7335.0 & & & 8343.72 & & \\
\hline LSD row & 9834.0 & & & 11244.98 & & \\
\hline
\end{tabular}

* Means followed by the same lowercase letter in the column and capital letter in the row do not differ by Tukey test at the level of $5 \%$.

For the cultivation in the dry season, plants of the genotypes BRS SEDA and CNPA G4 with Stimulate ${ }^{\circledR}$ show the greatest biological productivity (Table 7). According to Silva et al. (2014) in order to reach high productivity in the sesame crop it is necessary to perform good crop management in the field, so that it can reach its maximum potential. Sesame needs particular amounts of both water and nutrients, and proper management of these resources increases productivity.
Table 8 shows the average yield data of sesame grains in the two crop years and it is noticed that in the wet season (2014) the genotypes Lineage 1 and Lineage 2 with Stimulate ${ }^{\circledR}$ had higher yields compared to the plants without Stimulate ${ }^{\circledR}$. The genotypes Lineage 1 and Lineage 2 showed the highest grain weight, differing from genotypes BRS SEDA and CNPA G4. In the dry season (2015), the genotypes BRS SEDA and CNPA G4 with Stimulate ${ }^{\circledR}$ were higher in grain yield than the other genotypes (Table 8).

Table 8. Grain Productivity (GPROD) of plants of four sesame (Sesamum indicum L.) genotypes, with Stimulate $^{\circledR}$ (WITH) and without Stimulate ${ }^{\circledR}$ (WITHOUT) in the water season (2014) and in the dry season (2015). Garanhuns-PE.

\begin{tabular}{lllllll}
\hline \multicolumn{2}{c}{ GPROD Kg.ha } \\
\hline Genotypes & \multicolumn{2}{l}{ Water season (2014) } & \multicolumn{5}{l}{ Dry season (2015) } \\
\hline & WITH & WITHOUT & Mean & WITH & WITHOUT & Mean \\
BRS SEDA & $304.9 \mathrm{bA}$ & $207.5 \mathrm{aA}$ & $256.2 \mathrm{c}$ & $372.1 \mathrm{bA}$ & $173.7 \mathrm{aB}$ & $272.9 \mathrm{ab}$ \\
Lineage 1 & $824.5 \mathrm{aA}$ & $388.7 \mathrm{aB}$ & $606.6 \mathrm{ab}$ & $231.2 \mathrm{bA}$ & $170.4 \mathrm{aA}$ & $200.8 \mathrm{~b}$ \\
Lineage 2 & $1076.4 \mathrm{aA}$ & $437.3 \mathrm{aB}$ & $756.9 \mathrm{a}$ & $236.7 \mathrm{bA}$ & $197.2 \mathrm{aA}$ & $216.9 \mathrm{~b}$ \\
CNPA G4 & $432.2 \mathrm{bA}$ & $221.9 \mathrm{aA}$ & $327.1 \mathrm{bc}$ & $590.8 \mathrm{aA}$ & $142.4 \mathrm{aB}$ & $366.6 \mathrm{a}$ \\
\hline Mean & $659.5 \mathrm{~A}$ & $313.9 \mathrm{~B}$ & & $357.7 \mathrm{~A}$ & $170.9 \mathrm{~B}$ & \\
\hline CV column (\%) & 37.62 & & & 24.14 & & \\
CV row (\%) & 36.51 & & 32.11 & & \\
LSD column & 266.11 & & & 110.40 & & \\
LSD row & 357.19 & & & 148.03 & & \\
\hline
\end{tabular}

In the two years of cultivation, overall, Stimulate $^{\circledR}$ application favored productivity, which had a two-fold increase (Table 8). Beltrão et al. (2001) stated that in order to achieve an average yield of $1500 \mathrm{~kg} \mathrm{ha}^{-1}$ of seed in a rainfed regime, it is necessary to consider some aspects such as the genetic potential of the cultivar, the climate of the region, soil for cultivation, fertilization as well as phytosanitary factors. Morphological and physiological assessments of sesame when properly performed without interference of harmful organisms to the crop result in cultivars that can achieve high yield, surpassing the world average (FURAT; UZUN, 2010; ANASTASI et al, 2017).

Results of the chlorophyll A content (Tables 5), chlorophyll B content (Table 6) and grain yield (table 8) show that there is a relationship between chlorophyll content and increased productivity when Stimulate ${ }^{\circledR}$ is applied. The presence of chlorophyll is related to photosynthetic activity, which is responsible for the generation of energy and carbohydrates (ZHANG et al., 2015), which 
contributes directly to the increase of grain production. However, this increase in productivity varied among the different genotypes according to the crop year.

\section{CONCLUSIONS}

Phytostimulant application did not influence root length. However, it increased the number of fruits per plant and, in genotypes Lineage 1 and Lineage 2, also increased chlorophyll A and B content.
The application of phytostimulant increases the productivity in sesame; however, the response to phytostimulant application varies with genotype and growth conditions.

\section{ACKNOWLEDGMENT}

To the Federal Rural University of Pernambuco, Academic Unit of Garanhuns and to the Postgraduate Program in Agricultural Production (PGPA) for the opportunity to carry out the research. And to Stoller Company for the supply of biostimulant Stimulate ${ }^{\circledR}$.

RESUMO: O Gergelim (Sesamum indicum L.) é uma das espécies vegetais mais antigas cultivadas pelo homem, e tem se tornado uma alternativa importante para minimizar o agravante quadro de carência alimentar das populações de baixa renda. Os reguladores de crescimento influenciam o metabolismo proteico, podendo aumentar a taxa de síntese de enzimas envolvidas no processo de germinação das sementes, enraizamento, floração e frutificação das plantas. Desta forma este trabalho visou avaliar o desempenho agronômico de genótipos de gergelim sob a influência da aplicação do biorregulador Stimulate ${ }^{\circledR}$ em dois anos agrícolas nas condições do semiárido nordestino. O experimento foi realizado nos anos agrícolas, na estação chuvosa (2014) e na estação seca (2015) na cidade de Garanhuns-PE. O experimento foi conduzido em blocos casualizados, com a utilização de quatro genótipos de gergelim (BRS SEDA, CNPA G4, Linhagem 1 e Linhagem 2), com e sem aplicação do fitoestimulante (Stimulate ${ }^{\circledR}$ ). A aplicação do fitoestimulante não influenciou no comprimento de raiz. Porém, proporcionou aumento no número de frutos por planta e nos genótipos Linhagem 1 e Linhagem 2 promoveu também aumento no teor de clorofila A e B. A aplicação do fitoestimulante aumenta a produtividade, entretanto, a resposta à aplicação vai variar com o genótipo e condições de cultivo. A aplicação de fitoestimulante aumenta a produtividade na cultura do gergelim, no entanto, a resposta à aplicação irá variar com o genótipo e condições de crescimento.

PALAVRAS-CHAVE: Produtividade. Biorregulador vegetal. Rendimento de planta.

\section{REFERENCES}

ANASTASI, U.; SORTINO, O.; TUTTOBENE, R.; GRESTA, F.; GIUFFRÈ, A. M.; SANTONOCETO, C. Agronomic performance and grain quality of sesame (Sesamum indicum L.) landraces and improved varieties grown in a Mediterranean environment, Genetic Resources and Crop Evolution, v. 64, n. 1, p. 127-137, 2017. Disponível em: <https://link.springer.com/article/10.1007/s10722-015-0338-z>. Acesso em: 06 jul. 2017

ARGENTA, G.; SILVA, P. R. F.; BORTOLINI, C. G. Clorofila na folha como indicador do nível de nitrogênio em cereais. Ciência Rural, Santa Maria, v. 31, n. 04, p. 715-722, 2001. Disponível em: < http://www.scielo.br/scielo.php?script=sci_arttext\&pid=S0103-84782001000400027>. Acesso em: 06 jul. 2017

ARRIEL, N. H. C.; FIRMINO, P. T.; BELTRÃO, N. E. M.; SOARES, J. J.; ARAÚJO, A. E.; SILVA, A. C.; FERREIRA, G. B. A cultura do gergelim. Brasília: EMBRAPA, 2007. 72p.

AZEVEDO, M. R. Q. A.; GOUVEIA, J. P. G.; TROVÃO, D. M. M.; QUEIROGA, V. P. Influência das embalagens e condições de armazenamento no vigor de sementes de gergelim. Revista Brasileira de Engenharia Agrícola eAmbiental, Campina Grande, v. 7, n. 3, p. 519-524, 2003. Disponível em: < http://www.scielo.br/scielo.php?script=sci_arttext\&pid=S1415-43662003000300019>. Acesso em: 04 jul. 2017

BELTRÃO, N. E. M.; VIEIRA, D. J.O agronegócio do gergelim no Brasil. Brasília: EMBRAPA, 348 p, 2001. 
BOUREIMA, S., EYLETTERS, M., DIOUF, M., DIOP, T. A., E VAN DAMME, P. Sensitivity of seed germination and seedling radicle growth to drought stress in sesame (Sesamum indicum L.). Research Journal of Environmental Sciences, v. 5, p. 557-564, 2011. Disponível em: <

http://scialert.net/qredirect.php?doi=rjes.2011.557.564\&linkid=pdf>. Acesso em: 05 jul. 2017

BOURSCHEIDT, C. E. Fitorreguladores e seus efeitos agronômicos na cultura da soja (GlycinemaxL.). Ijuí: Universidade Regional do Noroeste do Estado do Rio Grande doSul, 2011. 35p. Trabalho de Conclusão de Curso.

CASTRO, P. R. C.; VIEIRA, E. L.Ação de bioestimulante na cultura do feijoeiro. In: FANCELLI, A.L.; DOURADO NETO, V. (Ed.). Feijão irrigado: tecnologia e produtividade. Piracicaba: Esalq, 2003.

CATO, S. C. Ação de bioestimulante nas culturas do amendoinzeiro, sorgo e trigo e interações entre auxinas, citocininas e giberelinas. Tese de doutorado, Universidade de São Paulo, Piracicaba, São Paulo. (2006).

CAVALCANTE, F. J. de A. (Coord.). Recomendações de adubação para o estado de Pernambuco: $2^{\text {a }}$.aproximação. 2 ed. ver. Recife, PE: IPA, 2008. 212 p.

FLOSS, E. L. Fisiologia de plantas cultivadas: o estudo que está por trás do que se vê. $4^{\mathrm{a}}$ ed., Passo Fundo: UPF, 733p, 2008.

FRANCIS, E. Sesame: For the Cooperative Extension Service University of Arkansas System Division of Agriculture. (2013), 190p.

FURAT, S.; UZUN, B. The use of agro-morphological characters for the assessment of genetic diversity in sesame (Sesamum indicum L.). PlantOmics, Austrália, v. 3, n. 3, p. 85-91. 2010. Disponível em: < http://search.informit.com.au/documentSummary;dn=122978591918140;res=IELHSS >. Acesso em: 06 jul. 2017

INSTITUTO BRASILEIRO DE METEREOLOGIA (INMET). Estação automática: Garanhuns-A322[on-line]. 2012. Disponível em: www.inmet.gov.br/. Acesso em 04 de março 2015.

KUCERA, B.; COHN, M. A.; LEUBNER-METZGER, G. Plant hormone interactions during seed dormancy release and germination. Seed Science Research. V. 15: p. 281-307, 2005. Disponível em: <

https://www.cambridge.org/core/journals/seed-science-research/article/plant-hormone-interactions-during-seeddormancy-release-and-germination/49880492C795ACB6909D6AB6C7FA80E7>. Acesso em: 05 jul. 2017

MAGALHÃES, B. S. N.; VIERA, M. C. R. Hormônios vegetais. Ciências Biológicas, UFRJ- RJ. 2008. Disponível em:

$<$ http://www.projetofundao.ufrj.br/biologia/images/materiais/hormonios_vegetais_mariana_cabrera_barbara_ne il.pdf $>$. Acesso em: 25 de janeiro de 2014.

MISGANAW, M.; MEKBIB, F.; WAKJIRA, A. Genotype x environment interaction on sesame ( Sesamum indicum L.) seed yield. Academic Journals, v. 10, n. 21, p. 2226-2239, 2015. Disponível em: < http://www.academicjournals.org/journal/AJAR/article-full-text-pdf/DB48A6753135>. Acesso em: 05 jul. 2017

NEVES, O. S. C.; CARVALHO, J. G. de.; MARTINS, F. A. D.; PÁDUA, T. R. P; PINHO, P. J. de. Uso do SPAD-502 na avaliação dos teores foliares de clorofila, nitrogênio, enxofre, ferro e manganês do algodoeiro herbáceo. Pesquisa Agropecuária Brasileira, v. 40, p. 517-521, 2005. Disponível em: < http://www.scielo.br/scielo.php?script=sci_arttext\&pid=S0100-204X2005000500014>. Acesso em: 06 jul. 2017 
OYEOGBE, A.; OGUNSHAKIN, R.; VAGHELA, S. E PATEL, B. Towards sustainable intensification of sesame-based cropping systems diversification in northwestern India. Journal of Food Security, v. 3,p. 1-5 , 2015. Disponível em: < http://pubs.sciepub.com/jfs/3/1/1/>. Acesso em: 04 jul. 2017

PEREIRA, J. R.; BELTRÃO, N. E. M.; ARRIEL, N. H. C.; SILVA, E. S. B. Adubação orgânica do gergelim, no seridó paraibano. Revista Brasileira de Oleaginosas e Fibrosas, Campina Grande, v. 6, n. 2, p. 515-523, 2002.

PHILOSOPH-HADAS, S.; FRIEDMAN, H.; MEIR, S. Gravitropic bending and plant hormones. Vitamins \& Hormones. V. 72, p. 31-78, 2005. Disponível em: < http://www.sciencedirect.com/science/article/pii/S0083672905720021>. Acesso em: 05 jul. 2017

RICHARDSON, A. D.; DUIGAN, S. P.; BERLYN, G. P. An evaluation of noninvasive methods to estimate foliar chlorophyll content. New Phytologist, v. 153, p. 185-194, 2002. Disponível em: < http://onlinelibrary.wiley.com/doi/10.1046/j.0028-646X.2001.00289.x/full>. Acesso em: 06 jul. 2017

RIGON, J. P. G.; BELTRÃO, N. E. M.; CAPUANI, S.; BRITO NETO, J. F.; SILVA, F. V. F. Análise não destrutiva de pigmentos fotossintéticos em folhas de gergelim. Revista Brasileira de Engenharia Agrícola e Ambiental, Campina Grande, v. 16, n. 3, p. 258-261, 2012. Disponível em: < http://www.scielo.br/scielo.php?script=sci_arttext\&pid=S1415-43662012000300004>. Acesso em: 06 jul. 2017

SILVA, J. C. A.; FERNANDES, P. D.; BEZERRA, J. R. C.; ARRIEL, N. H. C.; CARDOSO, G. D. Crescimento e produção de genótipos de gergelimem função de lâminas de irrigação. Revista Brasileira de Engenharia Agrícola e Ambiental, v. 18, n. 4, p. 408-416, 2014. Disponível em: < http://www.scielo.br/scielo.php?script=sci_arttext\&pid=S1415-43662014000400008>. Acesso em: 05 jul. 2017

SILVA, R. T.; OLIVEIRA, A. B.; LOPES, M. F. Q.; GUIMARÃES, M. A.; DUTRA, A. S. Physiological quality of sesame seeds produced from plants subjected to water stress. Revista Ciência Agronômica, v. 47, n. 4, p. 643-648, 2016. Disponível em: < http://www.scielo.br/scielo.php?script=sci_arttext\&pid=S180666902016000400643\&lang=pt>. Acesso em: 05 jul. 2017

STIRBET, A.; GOVINDJEE. On the relation between the Kautsky effect (chlorophyll a fluorescence induction) and Photosystem II: Basics and applications of the OJIP fluorescence transient. Journal of Photochemistry and Photobiology B: Biology, v. 104, p. 236-257, 2011. Disponível em:

<http://www.sciencedirect.com/science/article/pii/S1011134410002812>. Acesso em: 04 jul. 2017

YOUSEFZADEH, M.; EHSANZADEH, P. Salicylic acid effects on osmoregulation and seed yield in droughtstressed sesame. Agronomy Journal, v. 109, n. 4, pp. 1414-1422, 2017. Disponível em: < https://dl.sciencesocieties.org/publications/aj/articles/109/4/1414>. Acesso em: 06 jul. 2017

ZHANG, C.; ZHANG, W.; REN, G.; LI, D.; CAHOON, R. E.; CHEN, M.; ZHOU, Y.; YU, B.; CAHOON, E. B. Chlorophyll Synthase under Epigenetic Surveillance Is Critical for Vitamin E Synthesis, and Altered Expression Affects Tocopherol Levels in Arabidopsis. Plant Physiology, v. 168, pp. 1503-1511, 2015. Disponível em: < https://www.ncbi.nlm.nih.gov/pmc/articles/PMC4528762/>. Acesso em: 04 jul. 2017. 